Competition for resources among different groups is further illustrated in the three papers included in the third section: 'Competing Claims Over Nature.' Excerpts from V. Elwin's (1939) classic ethnography The Baiga of Central India, for example, describe how British colonial officials' establishment of commercial forestry and effort to wean the tribe away from "inferior" shifting cultivation caused irreparable damage to the Baiga economy and culture. The second paper, authored by the editor of the volume, describes a similar conflict between the state forestry and local peasants in the Kumaun region to whom access to forests and pastures was crucial for their economic activities. In the last paper, written especially for the volume, R. Sukumar provides a highly interesting analysis of the conflict between wild life and humans competing for the same natural resources.

The final section of the volume, 'Towards an Environmental Renewal,' includes only two papers, both of which, according to the words of the editor, are "at once reflective and programmatic" and offer diagnoses of "the social processes behind ecological degradation even as they outline the elements of an environmentally benign, and socially humane, strategy of development" (p.319). In his paper, A.K.N. Reddy cautions against injudicious adoption and application of modern technology by developing countries without first assessing their effects on the natural environment and the existing sociocultural conditions. A. Agarwal in the last paper also illustrates the connection between intensification of resource use through modern technology and environmental degradation and poverty.

The volume, meant primarily for use by students, will no doubt serve as an excellent text for a course on social ecology. As the first such volume of readings on social ecology in India, the book indeed provides a "compact and analytically sophisticated overview "of the field, as claimed on the jacket. The publishers must be congratulated for the Oxford in India Readings in Sociology and Social Anthropology series, not only for the superior quality of the volumes published so far, but also for their careful printing and fine production.

\title{
Land in African Agrarian Systems. Thomas J. Bassett and Donald E. Crummey, editors. Madison, WI. and London: University of Wisconsin Press. 1993. xi, 418 pp.
}

\section{Reviewed by Stephen P. Reyna, Professor and Chair of Anthropology, University of New Hampshire, Durham.}

The University of Illinois, Urbana-Champaign, during its Center for African Studies 1988 spring symposium, considered the topic of land in African agrarian systems. The resulting volume, Land in African Agrarian Systems, includes an introduction and thirteen papers analyzing African land tenure in the 1970s and 1980s. Below I give readers some appreciation of the substance of these papers and of a research priority that they suggest.

The volume is divided into three sections: one addressing questions of flexibility and conflict in indigenous landholding systems, another concerning access to land and agrarian politics, and a third considering agricultural performance under conditions of 
radical agrarian reform. (Papers, with the exception of the introduction, are discussed in the order that they appear in the volume.)

There are five papers in the first section. John Bruce's piece responds to criticisms of indigenous tenure systems concerning their adequacy with regard to investment security, efficient resource allocation, the securing of credit, and land transfers. Steven Lawry and Mahir Saul write respectively about Lesotho and Burkina Faso. Their case studies emphasize the flexibility of indigenous tenure systems by explaining how land borrowing and leasing arrangements accommodate the needs of landless and commercial farmers in areas with different population densities. Saul further challenges the unilinear evolutionary model of land tenure that sees changes in tenure as inevitably leading to individual private property. Richard Werbner and Thomas Bassett analyze conflicts over land use and control in pastoral development. Werbner considers how "competive and disunited elites" accumulate land in Botswana. Bassett explains how a "technocratic" approach to livestock development generated conflict that obstructed both the expansion of livestock production and agricultural intensification in the Ivory Coast.

The second section consists of three articles. Michael Watts seeks to understand the "dissent" between husbands and wives over access to land in Gambian households due to a "tightly regimented" production regime introduced by an irrigated rice development project. He argues that this conflict involves "interpretive struggles over socially dominant representations" that are resolved through "negotiation." Fiona Mackenzie continues the analysis of struggles between men and women for access to land. She shows how Kikiyu men in Kenya seek to control land claimed by women through the manipulation of customary inheritance rules of the mbari, the basic, "traditional" kin and territorial unit. Peter Bloch considers changing patterns of land access in an irrigated rice project along the Senegal River showing how local elites, some with national political connections, seek to exclude subordinate groups, including women, from access to improved land.There are fives articles in the final, radical agrarian reform section. Okoth-Ogendo assesses tenure reform policies in eastern and southern Africa, on the basis of which he concludes that agrarian reform, as currently practiced, is unlikely to produce any "turnaround." Dessalegn Rahmato evaluates the consequences of Ethiopia's 1975 radical land reform decree. His evidence shows that peasant production, despite a massive channeling of resources to the collective sector, outperformed cooperatives and state farms. Michael Roth analyses the impacts of Somalia's land reform which also began in 1975. His data suggest increased peasant insecurity, rural land speculation by urban elites, and reduced flexibility of indigenous tenure systems with little progress made toward either productivity or equity. Merle Bowen focuses upon what happens when a country, in this case Mozambique, abandons an orthodox socialist path of agricultural development based on collective agriculture with a heavy reliance upon state farms in favor of one oriented to private and peasant farming. She finds, for one irrigated rice scheme, that output is up; but that this is "at the expense of greater inequality." The final contribution to the volume, that of Terence Ranger, analyses agrarian reform in the communal areas of Zimbabwe. Ranger shows how the category of "communal tenure" is a colonial construct. He further documents how established commercial farmers have succeeded in shifting the discussion from land redistribution for land hungry poorer farmers to tenure reform within Communal Areas, a discussion that furthers their interests.

Thomas Bassett has written a fine introduction that summarizes the authors' major findings, compares and integrates these, and--on the basis of this analysis--argues the volume's central conclusions: that present tenure reforms are not a "cure-all" for African agriculture, and that future reform strategies had best work with the "strengths" of 
indigenous systems if they propose to have any chance of success. I would go further and propose that the volume suggests an important research priority.

Downs and Reyna (1988) and Reyna (1987) have argued that African land distribution is becoming increasingly inequitable. The essays in this volume support this view. However, they document that the processes by which land inequalities are maturing are complex. Certainly, men acquire land at the expense of women; equally certainly, elites are concentrating land at the expense of everyone else. But, as Watts informs readers, women contest land grabs by their men, so that gender inequalities are not a foregone conclusion. Further, the concept of "elite" turns out to be extremely intricate. There are different sorts of local elites--including chiefs, nobles, religious leaders, regional officials, and regional businessfolk--as well as different sorts of national elites such as politicians with positions in the central government, officials in non-African bilateral or multilateral government agencies, and the officers of national and multinational firms. Sometimes these different elites can be in alliance, as appears to be the case Bloch describes for Senegal. At other times, they are in competition, as Werbner emphasizes for Botswana. Evidence from other areas of the globe with long established patterns of land concentration indicates that such distributions can be associated with indifferent agricultural performance. This means that explanation of growing inequalities in land distribution, especially as these are related to output and productivity, may be central to improving African agricultural performance, and thus should be accorded a priority in forthcoming African land tenure researches.

Finally, Thomas Bassett and Donald Crummey, the volume's editors, are to be congratulated. They have crafted one of the richest documents concerning African land tenure to ever appear. It is a must read for those interested in agriculture, development, and Africa.

\section{References}

Downs, R.E. and S.P. Reyna (editors).

1988. Land and Society in Contemporary Africa. Hanover, NH: University Press of New England.

Reyna, S.P.

1987. The Emergence of Land Concentration in the West African Savanna. American Ethnologist, 14(3):523-541.

\section{An Occasion for War: Civil Conflict in Lebanon and Damascus in 1860, by Leila Fawaz, University of California Press (1994) xv, 302 pp.}

\section{Reviewed by Akram Khater, Department of History, North Carolina State University, Raleigh, NC}

Leila Fawaz's book, An Occasion for War: Civil Conflict in Lebanon and Damascus in 1860 , is a mixture of rich historical detail and bare thread analysis. This discordant combination stems from the author's central purpose for writing this book. As Professor Fawaz states in her preface, she consciously digs up the events of the civil conflicts of the nineteenth century in order to find lessons pertinent to the civil war that wracked Lebanon 